Science and Common Sense: an Aristotelian Excursion. By W. R. Thompson. Pp. vii + 234. (London, New York and Toronto : Longmans, Green and Co., Ltd., 1937.) 7s. 6d. net. Dr. THOMPson is a biologist of distinction whose published work is characterized by depth and originality. In this book he has departed from his usual field of observation and experiment and set himself the task of examining certain aspects of present-day scientific thought. He contends that some of the paradoxical statements made in connexion with physical theory would, in other circumstances, be regarded as contrary to logic and common sense. Biologists, he says, show signs of being imbued with this same mental attitude owing to the influence of mathematical physics.

Dr. Thompson's views are developed in some eight chapters, and perhaps the most significant are those concerned with the use and abuse of mathematics and of philosophy. The concluding chapter examines certain concepts of evolution. While the doctrine of evolution is a long way from being played out, it seems to have lost much of its interest, workers to-day tending to pursue matters more capable of experimental verification. Attempts to extract from the world as it now is have not yielded the true history of its past. Without the help of philosophy, the legitimacy of the principle of evolution would be impossible to uphold. The rejection of philosophical methods and principles would ultimately turn scientific work into a mere cinematographic record of events. With reference to mathematics and biology, the author stresses that the growing tendency to restate biological problems mathematically is beginning to produce "a kind of sublimation of biological facts into mathematical figments" which are commonly believed to be their equivalents. This practice, he observes, leads to quite fallacious notions about living things.

We commend Dr. Thompson's book as a critical and suggestive analysis : it aims at showing up in proper perspective some tendencies of modern scientific thought.

\section{Zero to Eighty :}

being my Lifetime Doings, Reflections and Inventions, also my Journey around the Moon. By Akkad Pseudoman (Dr. E. F. Northrup). . Pp. xii $+283+15$ plates. (Princeton, N.J. : Scientific Publishing Co., 1937.) 3 dollars.

IT may not be generally known that there is a British Interplanetary Society and an American Rocket Society, the members of which are heralding the dawn of interplanetary travel. In his volume "Rockets through Space", published last year, Mr. P. E. Cleator, president of the former, has given an account of the unsuccessful attempts which have been made to make a rocket leave the earth and visit other planets. Dr. E. F. Northrup, in "Zero to Eighty", is very much more likely to convince us that such methods will ever succeed, for he is at great pains to give us scientific chapter and verse for every event in his imaginary journey around the moon and back.
The story is told as an autobiography-the life, inventions and reflections of a man of science, Dr. Akkad Pseudoman, living from A.D. 1920 until 2000 -and is claimed to present a reasonable scientific solution to the problem of escaping from the earth's gravitational attraction and navigating projectileships in celestial space. Dr. Northrup's projectile acquires its huge velocity by eddy-current thrust in a long coil of special design which is excited by three-phase current. It is steered by means of rockets.

Akkad Pseudoman has all manner of adventures. He has a Russian assistant, who is claimed by the Soviet Government when all his plans are ready and who organizes a rival flight. $\mathrm{He}$ is kidnapped and is rescued as a result of his wife's knowledge of chemistry. He makes a fortune and is able to found a School of Associative Science where sciencephilosophers are trained.

Dr. Northrup's book does not, it is true, provide the general reader with such delectable fare as does Jules Verne in "From the Earth to the Moon, and a Trip Round It"; but the scientific reader cannot fail to be interested in the technical argument, which is expounded with striking lucidity.

\section{River Flow Records}

By Capt. W. N. McClean. Series A : River Garry. Sheet No. 1. 1s. 6d. Sheet B : River Moriston. Sheet No. 1. 1s. 6d. Series C: River Ness. Sheets 1-14. In portfolio. 15s. (London: River Flow Records, 1937.)

THe hydrological activities of the private organization known as River Flow Records (director, Capt. W. N. McClean, Parliament Mansions, S.W.1) have been in evidence for some time, and the publications under notice represent the data accumulated over a period of several years in the basin of the River Ness, Inverness-shire. Records of the River Garry, one of the tributaries of the Ness, were instituted so far back as December 1912, and then, after a prolonged interval, were resumed in 1929 on the establishment of a water-level recorder at Invergarry, with fresh measurements of flow. The survey of the River Moriston, another tributary influent, was instituted in 1929, following the rejection of the West Highland Water Power Scheme. In both cases, from July 1929 until March 1931, the records were issued quarterly in tabular form. In the present publication, they, and the complete set of records for the River Ness, are given in graphical form, based on the wider range of flow-gauging made since 1931 .

It is obvious that these readings must be of great service to all who are concerned with the hydrology of the Ness Basin, as, indeed, to water engineers generally, and it is to be hoped that the organization will receive substantial public support from the purchase and circulation of these admirable charts, embodying, as they do, the results of prolonged and careful observation, carried out on scientific lines and rendered available in a compact and easily accessible form by the commendable enterprise of the undertaking.
B. C. 